\title{
Foraging behavior interactions between the invasive Nile Tilapia (Cichliformes: Cichlidae) and three large native predators
}

\author{
Tiago Birck ${ }^{1}$, Hugo José Message ${ }^{1,2}$, Gilmar Baumgartner ${ }^{2,3}$, Nyamien Yahaut \\ Sebastien $^{1,2}$ and Dirceu Baumgartner ${ }^{1,2}$
}

\begin{abstract}
The predator-prey relationships between juvenile Nile Tilapia Oreochromis niloticus and native fish species of the Paraná River basin, Brazil, were experimentally examined. Juveniles of $O$. niloticus were offered to three native predator species (Salminus brasiliensis, Pseudoplatystoma corruscans, and Brycon orbignyanus) in 2,000-L tanks with four levels of habitat complexity $(0 \%, 50 \%, 100 \%$ and RD (rocks and driftwood)). Predator efficiency was more variable among species $(S$. brasiliensis consumed $86.6 \%$ of the prey, P. corruscans $22.5 \%$ and B. orbignyanus $18.3 \%$ ) than among levels of habitat complexity, and S. brasiliensis was faster than the others in detecting and consuming the prey. The higher predatory efficiency observed for $S$. brasiliensis can be partially explained by its more aggressive behavior (it fed earlier and for longer) and its presence in the surface layer. Here, the presence of predators led to $O$. niloticus juveniles spending more time at the surface or remaining in schools to coexist at the bottom with the predators, as expected for cichlids under predatory pressure in natural environments. Our results suggest that preserving and restoring populations of $S$. brasiliensis (and also to some extent $P$. corruscans and B. orbignyanus) might help to control O. niloticus in the Paraná River basin.
\end{abstract}

Keywords: Invasion, Management, Oreochromis niloticus, Predation, Prey.

As relações predador-presa entre alevinos de Tilápia-do-Nilo Oreochromis niloticus e espécies de peixes nativos da bacia do rio Paraná, Brasil, foram examinadas experimentalmente. Dez alevinos de O. niloticus foram oferecidos a três espécies nativas de predadores (Salminus brasiliensis, Pseudoplatystoma corruscans e Brycon orbignyanus) em tanques de $2000 \mathrm{~L}$ com quatro níveis de complexidade ambiental $(0 \%, 50 \%, 100 \%$ e RD (rochas e galhos)). A eficiência predatória foi mais variável entre espécies ( $S$. brasiliensis consumiu $86,6 \%$, P. corruscans $22,5 \%$ e B. orbignyanus $18,3 \%$ dos alevinos) do que para complexidade ambiental, e $S$. brasiliensis foi mais rápido do que os outros em detectar e consumir a presa. A eficiência predatória de $S$. brasiliensis pode ser parcialmente explicada pelo seu comportamento mais agressivo (alimentou-se mais cedo e por mais tempo de experimento) e pela presença na área de superfície. A presença de predadores levou os alevinos de $O$. niloticus a passar mais tempo na superfície ou formar cardume para coexistir no fundo com os predadores, como o esperado para ciclídeos sob pressão predatória no campo. Nossos resultados sugerem que preservar e restaurar as populações de S. brasiliensis (principalmente, mas também $P$. corruscans e $B$. orbignyanus) podem ajudar no controle de $O$. niloticus na bacia do rio Paraná.

Palavras-chave: Invasão, Manejo, Oreochromis niloticus, Predação, Presa.

\section{Introduction}

Aquaculture is an important economic activity; however, it is also a major pathway for the introduction of aquatic non-native species (Naylor et al., 2001; Ortega et al., 2015; Padial et al., 2017; Alves et al., 2018). Escapes from fish farms and invasions of non-native aquatic species into the wild are frequently associated with ecological and economic damages (Chandra, Gerhardt, 2008; Leprieur et al., 2008;
Daga et al., 2016; Agostinho et al., 2018) and, against this backdrop, there is the paradigmatic issue that biological invasions are a major cause of biodiversity loss (Dirzo et al., 2014). Non-native species may prey upon native species or compete with them, catalyze ecosystem alteration and biotic homogenization (Olden, Poff, 2004), spread diseases, cause reductions in wild stocks, (e.g., Latini, Petrere Júnior, 2004) and decrease the economic value of rivers and lakes (Pimentel et al., 2005; Ellender, Weyl, 2014; Lima et al., 2018).

\footnotetext{
${ }^{1}$ Programa de Pós-Graduação em Ciências Ambientais, Universidade Estadual do Oeste do Paraná, R. da Faculdade, 645 - Jardim La Salle, 85903-000 Toledo, PR, Brazil. (TB) birck.tiago@hotmail.com, Dhttps://orcid.org/0000-0002-1042-4697; (HJM) hugomessage@gmail.com, Dhttps://orcid.org/0000-0002-6031-8577 (corresponding author).

${ }^{2}$ Grupo de Pesquisas em Recursos Pesqueiros e Limnologia (Gerpel), Universidade Estadual do Oeste do Paraná, Toledo, Paraná, Brazil. (NYS) nyamien@hotmail.com, Dhttps://orcid.org/0000-0002-5288-7593; (DB) baum.d@hotmail.com, Dhttps://orcid.org/0000-0001-9943-6290.

${ }^{3}$ Programa de Pós-Graduação em Recursos Pesqueiros e Engenharia de Pesca, Universidade Estadual do Oeste do Paraná, Toledo, Paraná, Brazil. (GB) gilmar_baum@yahoo.com.br, Ohttps://orcid.org/0000-0003-0912-482X.
} 
There is some evidence that the Nile Tilapia Oreochromis niloticus (Linnaeus, 1758), introduced for aquaculture purposes, has established populations worldwide outside its native ranges and become invasive (Lowe et al., 2000; Naylor et al., 2001; Vicente, FonsecaAlves, 2013; Padial et al., 2017). The negative effects of Nile Tilapia invasions on native biodiversity (OgutuOhwayo, 1990; Canonico et al., 2005), on the ecosystem services (Vitule, 2009; Vitule et al., 2009; Njiru et al., 2010) and on ecosystem features (Zaret, Paine, 1973; Attayde et al., 2007), are well documented, and follow expected patterns of biological invasions in aquatic ecosystems (Mollot et al., 2017; Agostinho et al., 2018). However, whereas we know that the Nile Tilapia is a very invasive species, the interaction with native predators, which may possibly feed on Nile Tilapia, remains unknown. In summary, the following questions remain unanswered: whether native predators consume Nile Tilapia, under what environmental conditions this occurs and, finally, whether native predators are capable of reducing the effects of Nile Tilapia invasion. Our study aimed to answer these questions.

The Nile Tilapia, Oreochromis niloticus, is an omnivorous species native to northern and eastern Africa. Oreochromis niloticus is one of the top ten species in the world (Lowe et al., 2000; Picker, Griffiths, 2011) most frequently introduced through aquaculture. The rearing of Nile Tilapia can be traced back to ancient Egyptian times (4,000 years ago), and the species was first introduced to African countries in the 1940s and 1950s and to Asian and South, Central and North American countries in the 1960s and 1970s. Market development and processing advances have led to a rapid expansion of the cultured Nile Tilapia since the mid-1980s. Oreochromis niloticus is the most cultivated fish species in the world (FAO, 2016) due to their desirable features for aquaculture, including rapid growth rates, high feed conversion rates, high disease resistance at high densities and high market acceptability (Welcomme, 1967; Hassanien et al., 2004). Nevertheless, the same characteristics that increased interest in the Nile Tilapia for aquaculture are responsible for turning this species into a potentially invasive pest in many environments. Rapid growth rates, high resistance to diseases and multiple spawning with parental care (males make nests for spawning (Turner, Robinson, 2000), increase the potential for colonization (Vicente, Fonseca-Alves, 2013; Padial et al., 2017). In summary, the colonization of new environments by Nile Tilapia causes a reduction in native species (Van der Waal, Bills, 2000) and changes the competitive structure of native communities (Magalhães et al., 2011; Vicente, Fonseca-Alves, 2013).

Controlling fish invasion is difficult because of the unfeasibility of removing all invasive organisms, particularly in large ecosystems (Zhang et al., 2016). Thus, understanding the relations of invasive species with the environment and with native species is vital. To fill the gaps (the remaining issues listed above) in knowledge of the Nile Tilapia as an invasive species, this study aimed to assess the predatory behavior of dourado, Salminus brasiliensis (Cuvier, 1816), pintado, Pseudoplatystoma corruscans (Spix, Agassiz, 1829) and piracanjuba, Brycon orbignyanus (Valenciennes, 1850), on Nile Tilapia under standardized laboratory conditions, together with the behavioral interactions between the non-native and native species. This study comprised four parts: 1) investigation of the time required to start prey consumption and the feeding rates over time, 2) predatory efficiency trials, 3 ) investigation of the behavior of the native predators and the Nile Tilapia and 4) investigation of the use of microhabitats by native predators and Nile Tilapia. The following hypotheses were tested: (i) the Nile Tilapia is preyed upon by each species of native predator and (ii) the level of habitat complexity has an influence on the behavior of native predators and Nile Tilapia. Hence, we aimed to assess whether the native predators' behavior and the habitat complexity could reveal their potential to control the Nile Tilapia, which are invasive in the Paraná River basin.

\section{Material and Methods}

Experimental procedures and design. Juveniles of Nile Tilapia, Oreochromis niloticus, and adults of Salminus brasiliensis, Pseudoplatystoma corruscans, and Brycon orbignyanus, were obtained from local fish farms. These native predator species were selected for testing because they are abundant in areas where Nile Tilapia escapes have been observed (Buitrago-Suaréz, Burr, 2007; Lima, 2007; Daga et al., 2016), giving rise to the inference that they might prey upon Nile Tilapia. All animals were transferred to the wet laboratory at the Instituto de Pesquisas em Aquicultura Ambiental (InPAA), Universidade Estadual do Oeste do Paraná (UNIOESTE), Toledo campus, in Paraná State, for acclimatization and use in laboratory experiments. Conspecific individuals were kept together for acclimatization in 2,000-L circular tanks for 15 days before the experiment started. During this period, the fish were kept in tanks with individual water recirculation systems at ambient temperatures $\left(25 \pm 1^{\circ} \mathrm{C}\right)$, treated with $5 \%$ potassium permanganate $\left(\mathrm{KMnO}_{4}\right)$ to avoid infections (Abdel-Tawaab, 2005) and subjected to a 12:12 light:dark cycle (photoperiod).

We used a completely randomized experimental design to investigate the behavior of both prey and predators under habitat structuring (referred to here as habitat complexity). The experiments were performed in 2,000-L tanks with individual water recirculation systems, to avoid crosscontamination of water from different tanks. The opaque walls of the tanks prevented any visual interference among the fish in adjacent trials. Dark panels were attached to the laboratory windows to prevent penetration of natural light. Artificial lamps above each tank controlled the 
photoperiod. We used four levels of habitat complexity (treatments): $0 \%, 50 \%, 100 \%$ and rocks and driftwood (hereafter RD). The $0 \%, 50 \%$ and $100 \%$ treatments were simulated with green plastic filaments $(80 \mathrm{~cm} \times 1.5 \mathrm{~cm} \times$ $0.5 \mathrm{~mm}$ ), used to imitate ribbon-like leaves of submerged macrophytes (Fig. 1). We used adhesive tape to stick each strip to the bottom of the tank, extending it to the surface, with a density of 200 filaments $/ \mathrm{m}^{2}$, adapting the procedures in Savino, Stein (1982), Santos et al. (2009) and Santos et al. (2012). The RD treatment was built with basaltic rocks $(3.52 \pm 0.34 \mathrm{~kg} / \mathrm{L})$ and driftwood (lengths $58.7 \pm 3.39 \mathrm{~cm}$ and widths $7.72 \pm 0.89 \mathrm{~cm})$. Three species combinations were investigated separately: $O$. niloticus x $S$. brasiliensis, $O$. niloticus x $P$. corruscans, and $O$. niloticus x B. orbignyanus.

After the acclimatization period, all the fish were measured and weighed. The Nile Tilapia were $30.0 \mathrm{~mm}$ (mean) \pm 0.01 (standard error) long and weighed $0.72 \mathrm{~g}$ \pm 0.01 , the $S$. brasiliensis were $125.5 \mathrm{~mm} \pm 0.39$ long and weighed $22.01 \mathrm{~g} \pm 1.80$, P. corruscans were $136.4 \mathrm{~mm} \pm$ 0.30 long and weighed $13.23 \mathrm{~g} \pm 0.95$ and $B$. orbygnianus were $130.9 \mathrm{~mm} \pm 0.19$ long and weighed $24.15 \mathrm{~g} \pm 1.56$. Ten Nile Tilapia were transferred to each tank and one predator was placed in it 48 hours (h) later (period with no food). Three replicates were performed for each of the levels of habitat complexity and each of the species combinations, i.e., 36 tanks were used simultaneously under a completely randomized design. Data collection started $6 \mathrm{~h}$ later. Subsequently, we recorded data at 12-h intervals ( 5 a.m. and 5 p.m.) at ambient temperature ( 25 $\pm 1^{\circ} \mathrm{C}$ ). Each observation lasted five minutes. The most frequent behavior of every individual was recorded at every visual census. An all-encompassing behavioral pattern was considered, in order to avoid pseudoreplication. The experiments were performed for five consecutive days. The experiments were carried out under the Conselho Federal de Medicina Veterinária (CFMV, 2002) ethical guidelines.

Two classes of behavior were analyzed for predators: I) use of microhabitat (surface, middle and bottom layers) and II) activity (inactive, swimming, stalking and attacking). In addition, three classes of behavior were recorded for the Nile Tilapia: I) use of microhabitat (surface, middle and bottom layers), II) activity (inactive, swimming and avoidance) and III) defensive strategy (schooling and dispersed).

Data analyses. A two-way ANOVA, followed by Tukey's method for all pairwise comparisons, was used to test differences in predatory efficiency (quantified as the number of consumed prey items at the end of the experiment) between native species at various levels of habitat complexity. For each level of habitat complexity, a repeated-measures ANOVA (rmANOVA) was used to test differences in predatory activity of the native species over time. Two-way MANOVA tests, considering the three predators as individual independent variables, were used to analyze: 1) the use of microhabitat (factors: habitat complexity and microhabitat) and 2) the activity (factors: habitat complexity and activity), for the native predators, together with 3) the use of microhabitat (factors: habitat complexity and microhabitat), 4) the activity (factors: habitat complexity and activity) and 5) defensive strategy (factors: habitat complexity and defensive strategy) for the Nile Tilapia. All statistical analyses were performed using STATISTICA 10 (StatSoft, 2011).

See Fig. 2 for a summary of experimental procedures, design and statistical analyses.

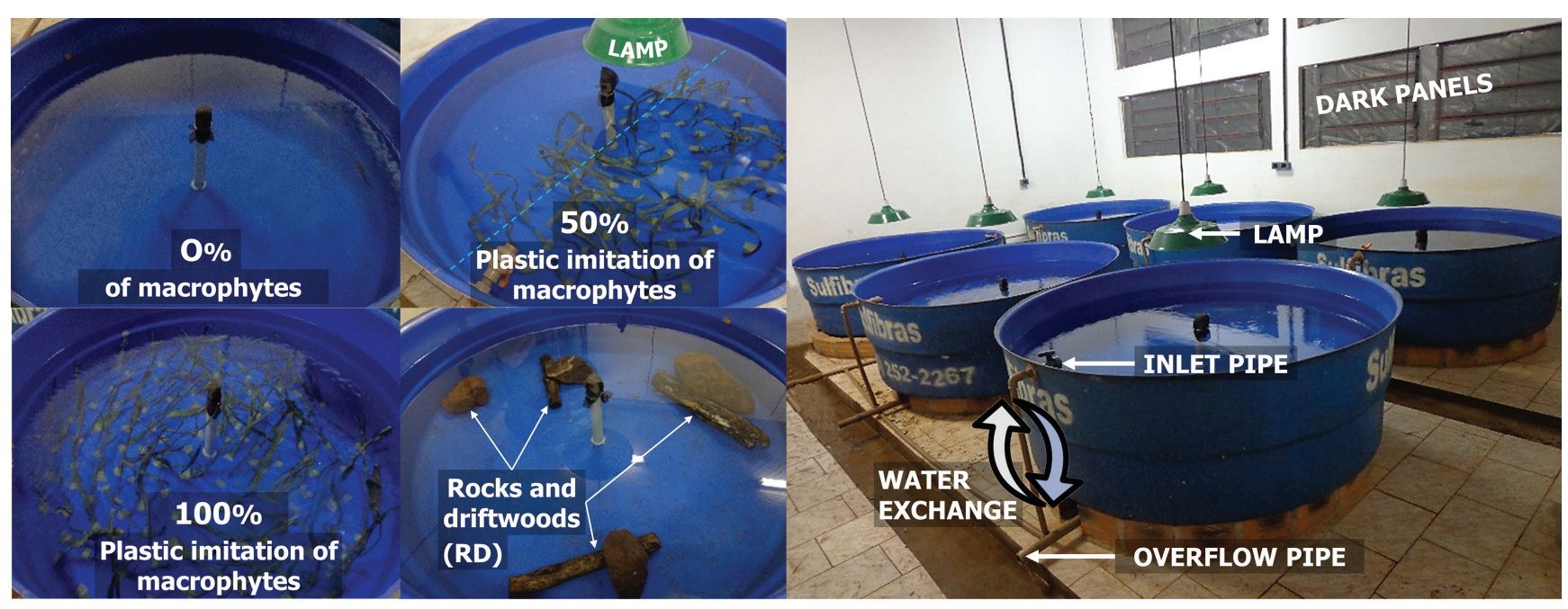

Fig. 1. Experimental tanks used. The left side of the image shows the simulation of habitat complexity using a plastic imitation of macrophytes: upper left $-0 \%$ habitat complexity, upper right $-50 \%$, bottom left $-100 \%$ and bottom right $-\mathrm{RD}$ (rocks and driftwood). The right side of the image shows the individual water circulation system, the lamps used to manipulate the photoperiod of 12:12 h light:dark and the dark panels at the windows to avoid the influence of natural light. 


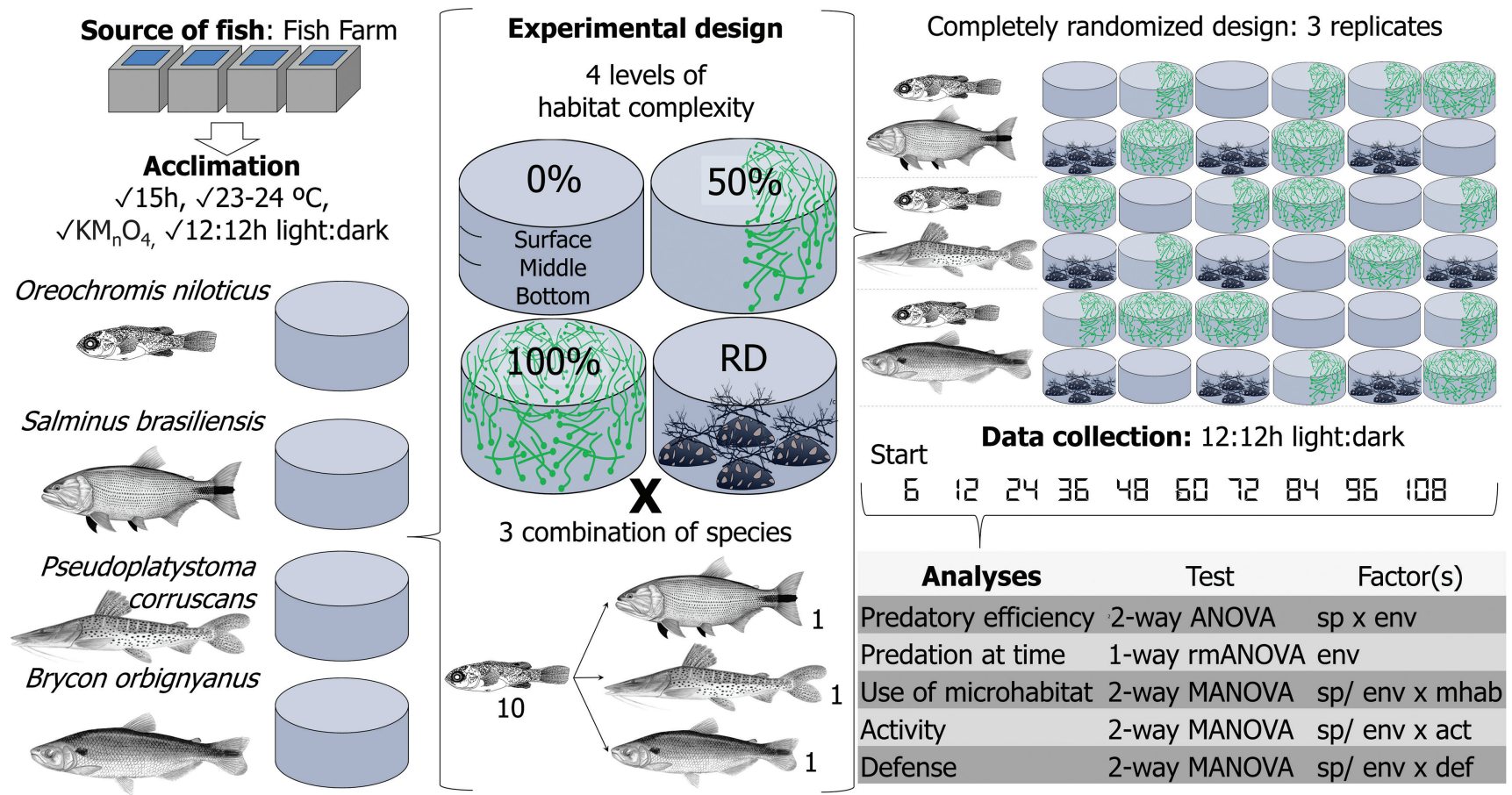

Fig. 2. Summary of scheme of experimental procedures, design and statistical analyses. From left to right: acclimatization period and procedures for each species in isolation (Oreochromis niloticus, Salminus brasiliensis, Pseudoplatystoma corruscans and Brycon orbignyanus). Experimental design: four levels of habitat complexity $(0 \%, 50 \%$ and $100 \%$ (simulated using green plastic filaments) and RD (rocks and driftwood) simulated with basaltic rocks and tree branches) for three species combinations ( $O$. niloticus $\mathrm{x} S$. brasiliensis, $O$. niloticus $\mathrm{x} P$. corruscans and $O$. niloticus $\times$ B . orbignyanus), replicated three times, totaling 36 experimental units. Ten $O$. niloticus were placed in each tank and after $6 \mathrm{~h}$, one predator was added. Data collection started $6 \mathrm{~h}$ from the beginning of the experiment and was repeated at 12-h intervals ( 5 a.m. $/ 5$ p.m.). The predatory efficiency, predation frequency over time, use of microhabitat and activity by predators and prey, together with the defense strategy of the prey, were analyzed using different models of ANOVA design.

\section{Results}

The results for predatory efficiency presented no significant interaction between species and habitat complexity (two-way ANOVA, $\mathrm{F}=0.65, \mathrm{P}=0.69$ ), and no significant differences between levels of habitat complexity (ANOVA, $\mathrm{F}=2.88, \mathrm{P}=0.06$ ), but showed that $S$. brasiliensis consumed significantly more Nile Tilapia than P. corruscans and B. orbignyanus (ANOVA, $\mathrm{F}=48.66, \mathrm{P}<0.01)$ (Fig. 3).

The rmANOVA presented significant differences in mean consumption of Nile Tilapia over time for all the four levels of habitat complexity. The differences were significant for $S$. brasiliensis in the $0 \%(\mathrm{P}<0.01$, Fig. 4a), 50\% ( $\mathrm{P}<0.01$, Fig. 4b), 100\% ( $<<0.01$, Fig. $4 \mathrm{c})$ and $\mathrm{RD}(\mathrm{P}<0.01$, Fig. $4 \mathrm{~d})$ levels and for $P$. corruscans in the $50 \%(\mathrm{P}=0.01$, Fig. $4 \mathrm{~b})$ level. The differences were not significant for $P$. corruscans in the $0 \%(\mathrm{P}=0.78$, Fig, $4 \mathrm{a})$, $100 \%(\mathrm{P}=0.13$, Fig. $4 \mathrm{c})$ or $\mathrm{RD}(\mathrm{P}=$ not calculated, Fig. $4 \mathrm{~d})$ levels or for $B$. orbygnianus in the $0 \%(\mathrm{P}=0.82$, Fig. 4a), $50 \%(\mathrm{P}=0.88$, Fig. $4 \mathrm{~b}), 100 \%(\mathrm{P}=0.90$, Fig. $4 \mathrm{c})$ or $\mathrm{RD}(\mathrm{P}=0.09$, Fig. 4d) levels.

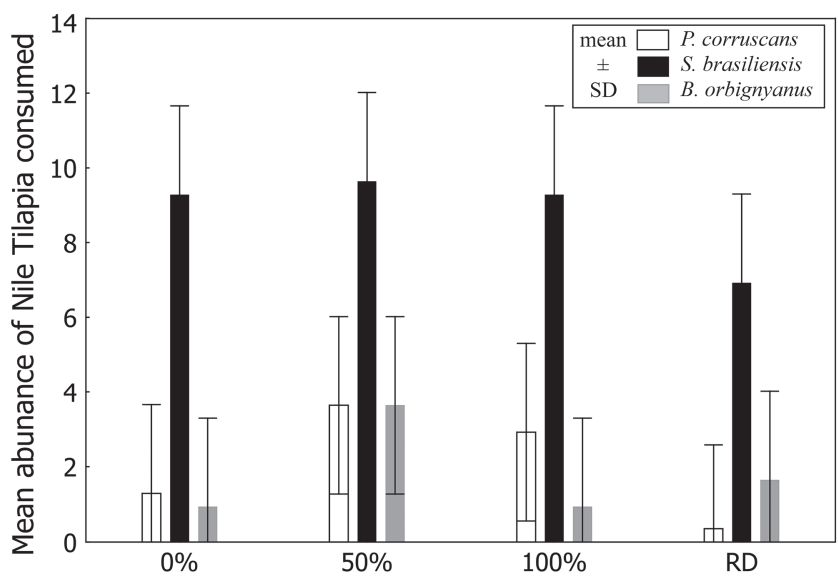

Fig. 3. Predatory efficiency (mean \pm standard deviation (SD) of Oreochromis niloticus consumption) by Pseudoplatystoma corruscans (white bars), Salminus brasiliensis (black bars) and Brycon orbignyanus (gray bars), in $0 \%, 50 \%, 100 \%$ and $\mathrm{RD}$ treatments. ANOVA for these data was not significant $(\mathrm{P}=0.69)$ for interaction between species and structural complexity. However, the predatory efficiencies of species were different $(\mathrm{P}<0.001)$. 

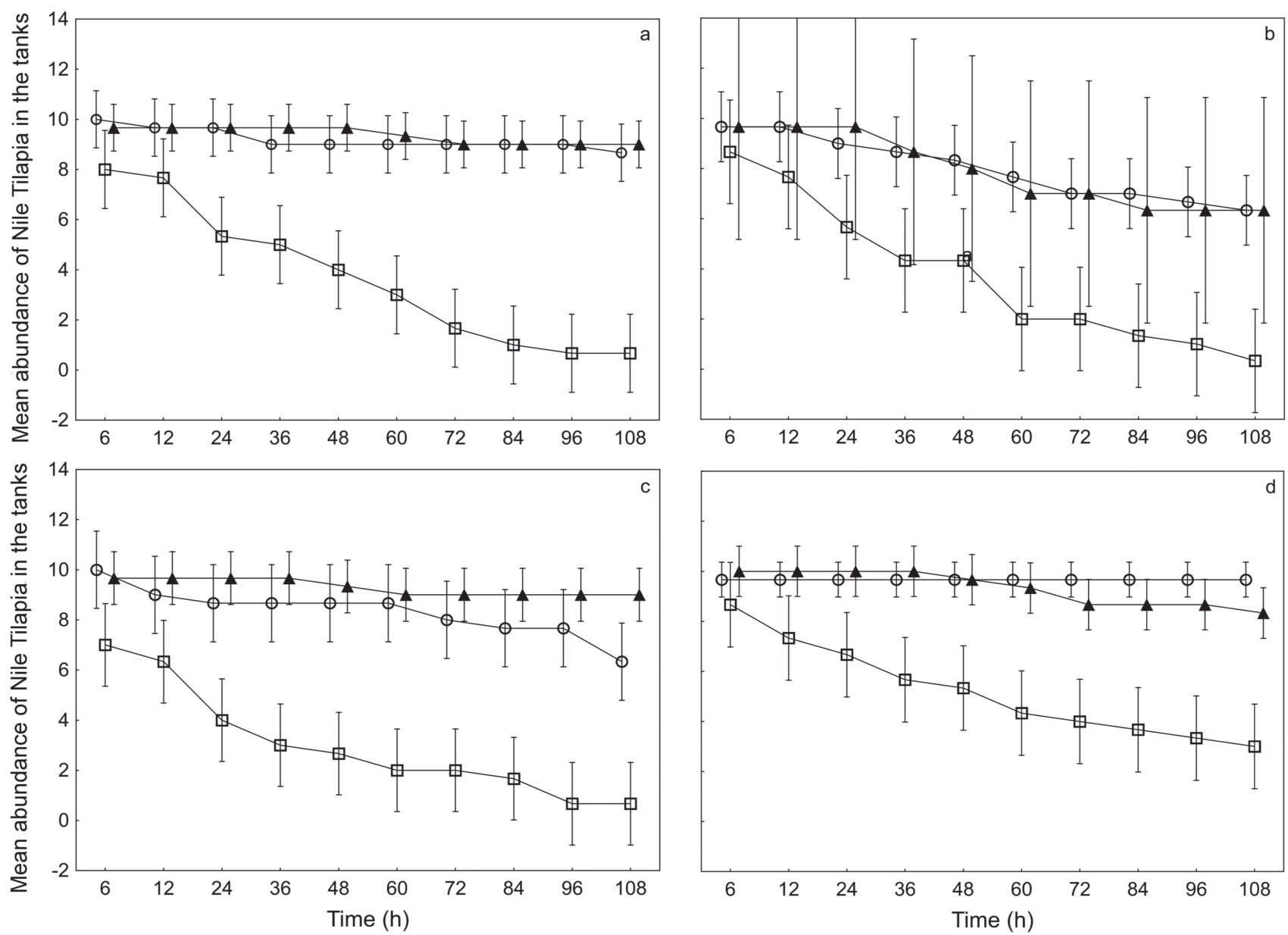

Fig. 4. Temporal variation of predatory activity the experiment, in each treatment. Mean \pm SD of Oreochromis niloticus survival in the tanks with Pseudoplatystoma corruscans (white circles), Salminus brasiliensis (white squares) and Brycon orbignyanus (black triangles). Levels of habitat complexity: a. $0 \%$, b. $50 \%$, c. $100 \%$ and d. RD.

The use of microhabitat by the native predators presented no significant difference (MANOVA, $\mathrm{F}_{9.36}=0.67, \mathrm{P}=0.73$ ) among levels of habitat complexity. However, there were significant differences between microhabitats (MANOVA, $\left.\mathrm{F}_{6.36}=28.5, \mathrm{P}<0.01\right)$ and significant interaction between habitat complexity and microhabitat (MANOVA, $\mathrm{F}_{18.36}=$ $2.01, \mathrm{P}=0.02)$. The univariate analysis showed that the three species of native predators spent more time at the bottom than in the middle or surface layers (Fig. 5).

The results of the two-way MANOVA for predator activity presented significant interaction between habitat complexity and activity (MANOVA, $\mathrm{F}_{2736}=3.96, \mathrm{P}<$ 0.01 ) and significant differences between activity levels (MANOVA, $\mathrm{F}_{9.36}=36.33, \mathrm{P}<0.01$ ), but not between habitat complexity levels (MANOVA, $\mathrm{F}_{9.36}=0.37, \mathrm{P}=0.94$ ) (Fig. 6). The native predators presented more active and swimming behavior than stalking or attacking behavior, and in fact the latter were not even observed.

In the use of microhabitat by the Nile Tilapia, there was significant interaction between habitat complexity and microhabitat (MANOVA, $\mathrm{F}_{18.36}=2.31, \mathrm{P}=0.01$ ) and significant differences among microhabitats (MANOVA,
$\left.\mathrm{F}_{6.36}=18.7, \mathrm{P}<0.01\right)$, but not among habitat complexity levels (Fig. 7). The use of the bottom and surface layers was similar and higher than the use of the middle layer for $S$. brasiliensis and for P. corruscans. The use of the bottom was higher than that of the surface, which was in turn higher than that of the middle, for B. orbignyanus.

The two-way MANOVA for Nile Tilapia activity presented significant interaction between habitat complexity and activity $\left(\mathrm{F}_{18.36}=1.32, \mathrm{P}=0.03\right)$ and significant differences in activity $\left(\mathrm{F}_{6.36}=79.38, \mathrm{P}<0.01\right)$ but not in habitat complexity $\left(\mathrm{F}_{936}=0.41, \mathrm{P}=0.92\right)$ (Fig. 8). Nile Tilapia showed more active behavior than swimming behavior, considering the presence of native predators. Escaping behavior was not observed.

The analysis of defensive strategy presented significant interaction between defensive strategy and habitat complexity (two-way MANOVA, $\mathrm{F}=3.34, \mathrm{P}=0.004$ ) and significant differences regarding defensive strategy (twoway MANOVA, $\mathrm{F}=30.61, \mathrm{P}<0.01)$, but not regarding habitat complexity (two-way MANOVA, $\mathrm{F}=0.88, \mathrm{P}=$ $0.55)$ (Fig. 9). Nile Tilapia presented more schooling than dispersing, in the presence of the three native predators. 


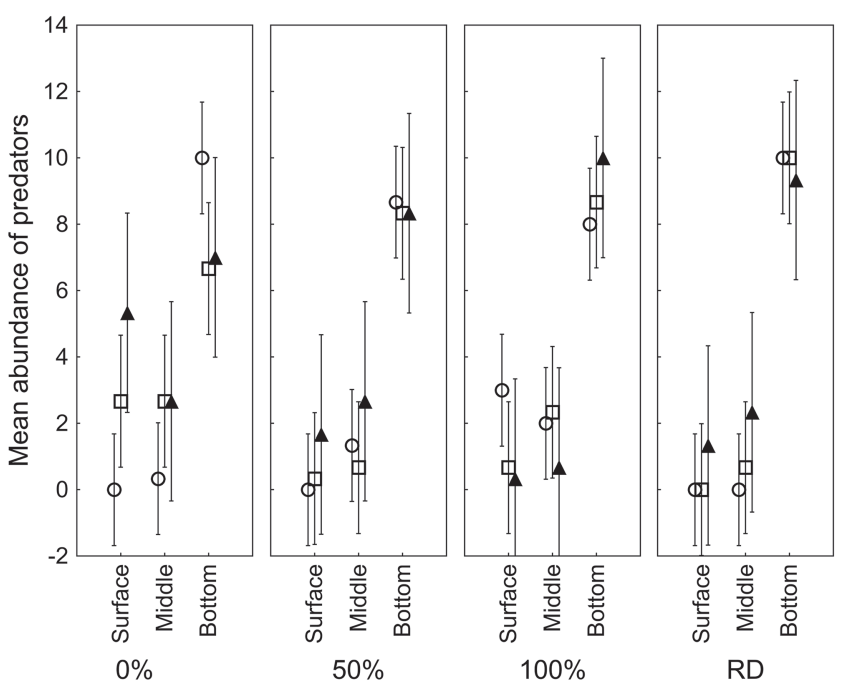

Fig. 5. Use of microhabitat (surface, middle and bottom layers) by the native predators (mean \pm SD) Pseudoplatystoma corruscans (white circles), Salminus brasiliensis (white squares) and Brycon orbignyanus (black triangles), for $0 \%, 50 \%, 100 \%$ and RD treatments. The three-way ANOVA for these data showed significant interaction $(\mathrm{P}=0.049)$ among species, structural habitat complexity and microhabitat. All species of native predators used the bottom layer of the tank more frequently.
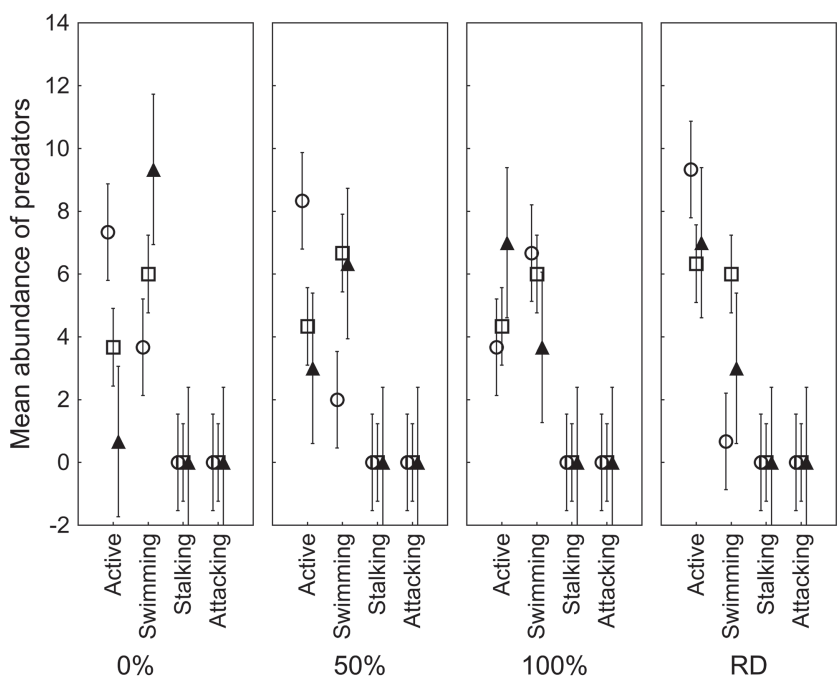

Fig. 6. Activity (inactive, swimming, stalking and attacking) by the native predators (mean $\pm \mathrm{SD}$ ) Pseudoplatystoma corruscans (white circles), Salminus brasiliensis (white squares) and Brycon orbignyanus (black triangles), for $0 \%, 50 \%, 100 \%$ and $\mathrm{RD}$ treatments. The three-way ANOVA for these data suggested that the interaction among species, structural habitat complexity and activity was significant $(\mathrm{P}<0.001)$. The native predators did not stalk or attack in any of the treatments.
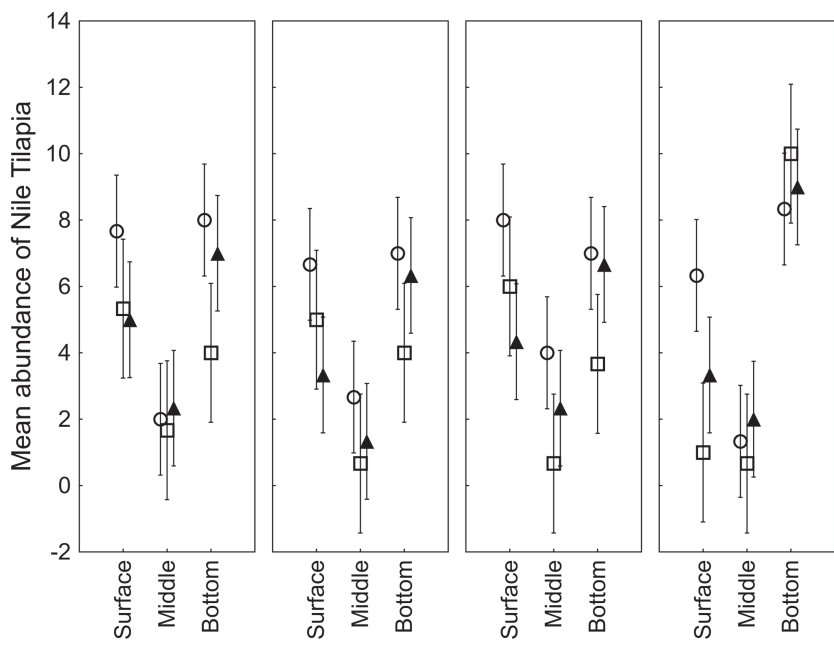

Fig. 7. Use of microhabitat (surface, middle and bottom) by the Nile Tilapia (mean \pm SD) in the tanks with Pseudoplatystoma corruscans (white circles), Salminus brasiliensis (white squares) and Brycon orbignyanus (black triangles), for $0 \%, 50 \%, 100 \%$ and $\mathrm{RD}$ treatments. The three-way ANOVA for these data suggested significant (P $=0.045$ ) interaction between species, structural complexity and use of microhabitat. The juveniles used the surface and bottom layers more frequently.
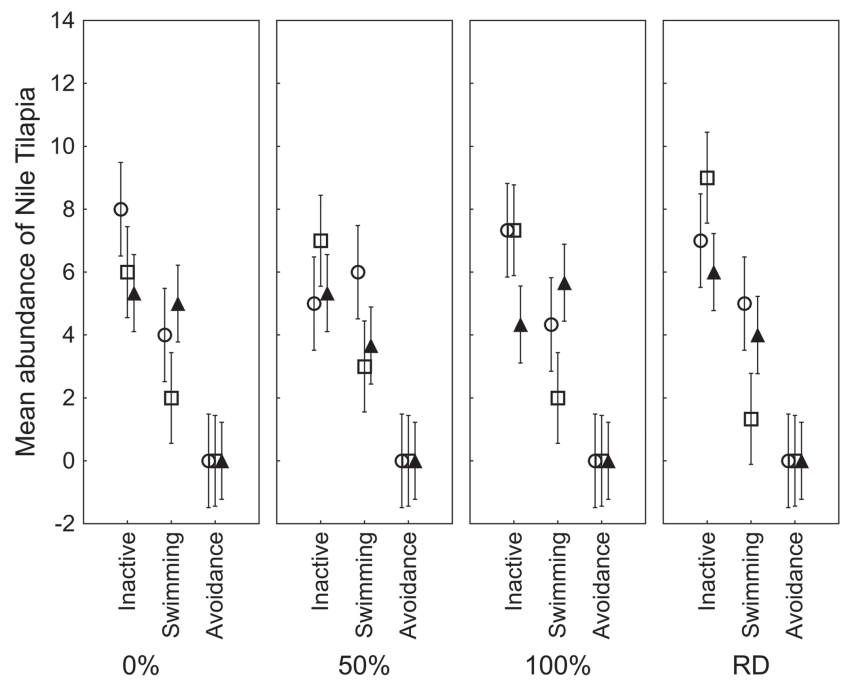

Fig. 8. Activity (inactive, swimming and avoidance) by the Nile Tilapia (mean $\pm \mathrm{SD}$ ) in the tanks with Pseudoplatystoma corruscans (white circles), Salminus brasiliensis (white squares) and Brycon orbignyanus (black triangles), for $0 \%$, $50 \%, 100 \%$ and RD treatments. The three-way ANOVA for these data suggested interaction ( $\mathrm{P}=0.029)$ among species, structural complexity and activity. The avoidance activity was not observed. 


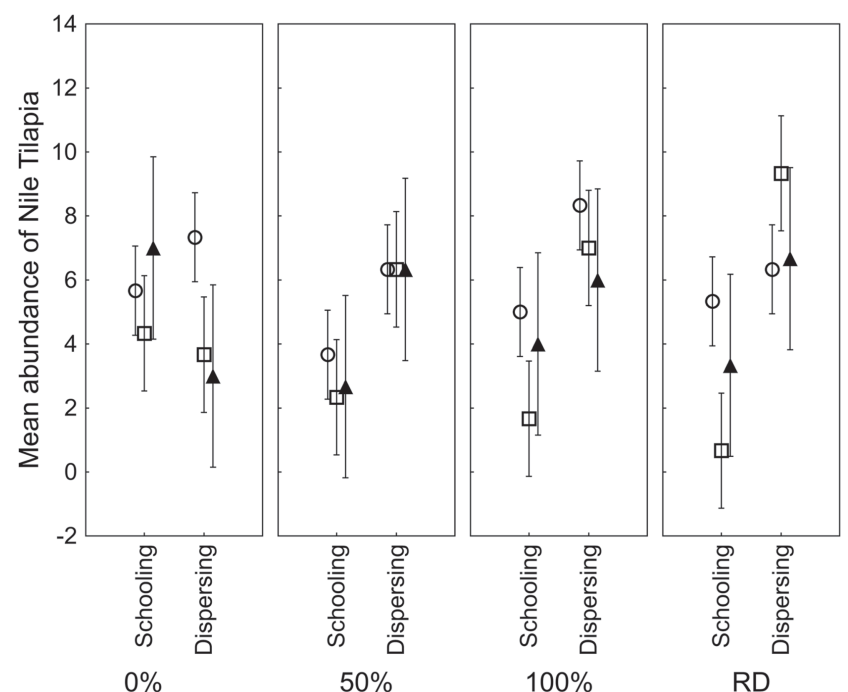

Fig. 9. Defense strategy (schooling and dispersing) by the Nile Tilapia (mean \pm SD) in the tanks with Pseudoplatystoma corruscans (white circles), Salminus brasiliensis (white squares) and Brycon orbignyanus (black triangles), for 0\%, $50 \%, 100 \%$ and RD treatments. The three-way ANOVA for these data showed interaction $(\mathrm{P}=0.018)$ among species, structural complexity and schooling. Shoaling decreased for $0 \%$ to $100 \%$ structural complexity treatments, while dispersing behavior increased for the RD treatment.

\section{Discussion}

Although both $S$. brasiliensis and $P$. corruscans fed on the Nile Tilapia, $B$. orbignyanus did not present the same pattern. We found no obvious influence of the habitat complexity. Salminus brasiliensis preyed upon $86.6 \%$ of the Nile Tilapia offered in the experiment, while P. corruscans preyed on $22.5 \%$ and B. orbignyanus preyed on $18.3 \%$. Together, they consumed $42.5 \%$ (153 out of 360 ) of the juveniles. From a predation standpoint, this result indicates that the Nile Tilapia is attractive to these species, mainly to $S$. brasiliensis. This difference between predator species should not be a surprise. Broader studies have already indicated that larger carnivores consume a wide array of small species and juveniles (Juanes et al., 2002; Bozza, Hahn, 2010; Santos et al., 2012), while B. orbignyanus has low potential as a consumer of Nile Tilapia (Santos et al., 2009). Furthermore, $P$. corruscans shows ambushing behavior in shallow areas with different densities of macrophytes (Sabino, Zuanon, 1998; Giaquinto, Hoffmann, 2010; Petry et al., 2010) and S. brasiliensis has high potential for predation and also good maneuvering and swimming abilities (Agostinho et al., 2007; Gubiani et al., 2010; Santos et al., 2013).

The feeding rate analysis showed that Salminus brasiliensis was faster than the other native predators in detecting Nile Tilapia. Several studies have shown that the foraging behavior might influence the outcomes of feeding interactions, (e.g., Freitas, Volpato, 2008). Consistent with this hypothesis, accepting the one-to-one trials for each species, S. brasiliensis was the most aggressive species, presenting predation behavior over the entire period of the experiment. It is hard to predict how this might affect feeding interactions under natural conditions, because of the competition with other predators and the different types of habitats, such as logs and mud, which are refuges for prey (Savino, Stein, 1982; Werner et al., 1983; Hanisch et al., 2012).

When the microhabitat use by predators was evaluated, it was found that the bottom layer was the most inhabited microhabitat for all three species. It is important to notice, however, that the tanks could have limited the space for swimming and, in a larger setting, Salminus brasiliensis and Brycon orbignyanus might be more defensive, as here they may be unable to swim to the middle layer and the surface, which would be their typical behavior in their natural habitats. Nevertheless, S. brasiliensis is an aggressive predator that can easily adapt to changes in environmental conditions (Gubiani et al., 2010). Most of the preys are also at the surface. These results suggest that predators choose habitats according to their prey's presence, which suggests, as a consequence, two defensive behaviors: inhabiting the surface and swimming in schools. The preference for habitats with resources (food) and without competition is extensively noted in the literature, as well as these defensive behaviors (Shaw, 1978) for Nile Tilapia (Freitas, Volpato, 2008).

All three species of predators were observed showing active or swimming behavior, but not stalking or attacking Nile Tilapia. This result is easy to explain for Brycon orbignyanus, given that no prey items were consumed. However, it was not expected for Pseudoplatystoma corruscans or for Salminus brasiliensis, as these species caught and consumed the juveniles. The behavior analysis for Nile Tilapia supports the explanation of these results, i.e., that the fish of this species were mostly found in the bottom layer, along with predators. In Brazil, S. brasiliensis and $P$. corruscans are common species, which are commercially important and widely distributed in several basins, including areas where the Nile Tilapia was detected. It seems then, that these two native predator species may prey upon Nile Tilapia in the wild and perhaps could contribute to controlling Nile Tilapia populations, once they become fully established.

The behavior of Nile Tilapia, like that of the predators, was not obviously influenced by the habitat complexity. However, we found significant effects of interaction between habitat complexity and microhabitat, habitat complexity and activity and habitat complexity and defensive strategy. The juveniles were encountered more frequently at the surface and bottom layers, matching the predators' presence. In this study, the presence of Nile Tilapia at the surface represents the maintenance of distance from predators (which were observed more frequently at the bottom), whereas the co-occurrence of prey with predators at the bottom, associated with aggregated rather than disperse behavior, revealed the importance of 
schooling as a defense for the juveniles. In summary, the Nile Tilapia in this study showed the expected behavioral pattern for cichlids under predatory pressure. Other studies have reported that, in the field, cichlids tend to stay slightly active at the bottom of lakes among submerged structures, especially macrophytes (Lowe-McConnell, 1991).

As we know from previous studies, there is a potential risk of negative impacts by invasive Nile Tilapia on native species, (e.g., competition for food and spawning grounds and dissemination of diseases) and on the invaded ecosystems, (e.g., eutrophication through bioturbation and predation of zooplankton (Attayde et al., 2007). However, the efforts to prevent invasions are mostly inefficient or may even not exist, regardless of the costs of biological invasions. The escape of Nile Tilapia from fish farms into natural ecosystems can occur during water exchange via the effluent water or during handling when emptying tanks, but mainly occurs due to the rupture or overflow of the tanks caused by peak floods not forecasted during the construction (Orsi, Agostinho, 1999; Ortega et al., 2015; Daga et al., 2016). Furthermore, it is a common practice of Brazilian fish farmers to establish their fish rearing in net tanks or near rivers, within areas of permanent preservation, consequently imperiling their outcomes with respect to unexpected flooding.

This study presented the potential of feeding interactions between Salminus brasiliensis and Pseudoplatystoma corruscans, two commercially important native species, and Nile Tilapia. These predators preyed upon the juveniles and forced them to inhabit the surface. The laboratory experiment suggests that the native $S$. brasiliensis is very capable of capturing and feeding on the non-native Nile Tilapia, and there is no reason to suppose that other native predators would avoid the Nile Tilapia. Our results on Brycon orbignyanus were unexpected and contrary to other studies, such as that of Santos et al. (2009), which reported that this predator consumed other prey species under experimental conditions. Thus, further studies on feeding interactions between $B$. orbignyanus and Nile Tilapia are needed. Currently, it is unknown whether other predators of Nile Tilapia would also prey upon them in the middle and surface microhabitats.

Considering the economic appeal of Nile Tilapia, Strictar-Pereira et al. (2010), Britton, Orsi (2012), Agostinho et al. (2018) and Alves et al. (2018), suggested that Tilapia production in inland areas would present lower ecological risks than rearing them in net tanks or near to rivers. The inland culture would lead to zero, or at least fewer, incidents of escapes of farmed Nile Tilapia into the wild. The choice of farming locations is important because aquaculture operations using Nile Tilapia are expected to grow in Brazil and other South American countries. Thus, preventive measures, such as strengthening the government control of non-native species invasion and developing guidance on a monitoring program for detecting the establishment and spread of Nile Tilapia, are critical. We suggest fostering communication among scientists, managers and fish farmers about the risks and negative effects caused by non-native species with respect to local fauna and ecosystems, in order to prevent the spread of invasive species and new incomers. In addition, in a best-case scenario, native predators will become controllers of the propagule pressure of Nile Tilapia in natural ecosystems, and therefore efforts to preserve them are very important. However, more studies are necessary to provide insights about interactions between the invasive Nile Tilapia and native predator species, and the consequences of the introduction of the Nile Tilapia for ecosystem as a whole. New experiments, giving to the predator the opportunity to choose between various prey species, could make it possible to envisage a more realistic community-level discussion.

\section{Acknowledgments}

We thank the Fundação Araucária the Coordenação de Aperfeiçoamento de Pessoal de Nível Superior (CAPES) and Programa Nacional de Pós-Doutorado (PNPD) MEC/ CAPES for scholarships (to HJM), Dr. Robie Allan Bomberdelli for assisting in supporting the infrastructure for the experiments and Gabriel Deprá (UEM) and Renata Ota (UEM/IFPR) for conceptual discussions.

\section{References}

Abdel-Tawwab M. Predation efficiency of Nile catfish, Clarias gariepinus (Burchell, 1822) on fry Nile tilapia, Oreochromis niloticus (Linnaeus, 1758): Effect of prey density, predator size, feed supplementation and submerged vegetation. Turk J Fish Aquat Sci. 2005; 5(2):69-74.

Agostinho AA, Pelicice FM, Petry AC, Gomes LC, Júlio Júnior HF. Fish diversity in the upper Paraná river basin: Habitats, fisheries, management and conservation. Aquat Ecosyst Health Manag. 2007; 10(2):174-86.

Agostinho AA, Vitorino Júnior OB, Pelicice FM. Riscos ambientais do cultivo de tilápia em tanques redes. Boletim SBI. 2018; 124:2-9.

Alves GHZ, Tófoli RM, Message HJ, Lima-Junior DP, Hoeinghaus DJ. New decree promotes fish invasion in the Amazon and Pantanal. Biodivers Conserv. 2018; 27(9):2449-50.

Attayde JL, Okun N, Brasil J, Menezes R, Mesquita P. Impactos da introdução da tilápia do Nilo, Oreochromis niloticus, sobre a estrutura trófica dos ecossistemas aquáticos do bioma Caatinga. Oecol Bras. 2007; 11(3):450-61.

Bozza AN, Hahn NS. Uso de recursos alimentares por peixes imaturos e adultos de espécies piscívoras em uma planície de inundação neotropical. Biota Neotrop. 2010; 10(3):217-26.

Britton JR, Orsi ML. Non-native fish in aquaculture and sport fishing in Brazil: Economic benefits versus risks to fish diversity in the upper River Paraná Basin. Rev Fish Biol Fisher. 2012; 22(3):555-65.

Buitrago-Suárez UA, Burr BM. Taxonomy of the catfish genus Pseudoplatystoma Bleeker (Siluriformes:Pimelodidae) with recognition of eight species. Zootaxa. 2007; 1512:1-38. 
Canonico GC, Arthington A, McCrary JK, Thieme ML. The effects of introduced tilapias on native biodiversity. Aquat Conserv. 2005; 15(5):463-83.

Chandra S, Gerhardt A. Invasive species in aquatic ecosystems: Issue of global concern. Aquat Invasions. 2008; 3(1):1-2.

Conselho Federal de Medicina Veterinária (CFMV). Resolução $\mathrm{N}^{\circ} 714$, de 20 de junho de 2002. Dispõe sobre procedimentos e métodos de eutanásia em animais e dá outras providências [Internet]. Brasília; 2002. Available from: http://portal.cfmv. gov.br/lei/index/id/327

Daga VS, Debona T, Abilhoa V, Gubiani EA, Vitule JRS. Nonnative fish invasions of a Neotropical ecoregion with high endemism: A review of the Iguaçu River. Aquat Invasions. 2016; 11(2):209-23.

Dirzo R, Young HS, Galetti M, Ceballos G, Isaac NJB, Collen B. Defaunation in the Anthropocene. Science. 2014; 345(6195):401-06.

Ellender BR, Weyl OLF. A review of current knowledge, risk and ecological impacts associated with non-native freshwater fish introductions in South Africa. Aquat Invasions. 2014; 9(2):117-32.

Food and Agriculture Organization of the United Nations (FAO). The state of world fisheries and aquaculture 2016: Contributing to food security and nutrition for all [Internet]. Rome; 2016. Available from: http:/www.fao.org/3/a-i5555e.pdf

Freitas RHA, Volpato GL. Behavioral response of Nile Tilapia to an allopatric predator. Mar Freshw Behav Phy. 2008; 41(4):267-72.

Giaquinto PC, Hoffmann A. Role of olfaction and vision cues in feeding behavior and alarm reaction in the catfish pintado, Pseudoplatystoma corruscans. J Ethol. 2010; 28(1):21-27.

Gubiani EA, Frana VA, Maciel AL, Baumgartner D. Occurrence of the non-native fish Salminus brasiliensis (Cuvier, 1816), in a global biodiversity ecoregion, Iguaçu River, Paraná River basin, Brazil. Aquatic Invasions. 2010; 5(2):223-27.

Hanisch JR, Tonn WM, Paszkowski CA, Scrimgeour GJ. Complex littoral habitat influences the response of native minnows to stocked trout: Evidence from whole-lake comparisons and experimental predator enclosures. Can J Fish Aquat Sci. 2012; 69(2):273-81.

Hassanien HA, Elnady M, Obeida A, Itriby H. Genetic diversity of Nile tilapia populations revealed by randomly amplified polymorphic DNA (RAPD). Aquac Res. 2004; 35(6):587-93.

Juanes F, Buckel JA, Scharf FS. Feeding ecology of piscivorous fishes. In: Hart PJB, Reynolds JD, editors. Handbook of fish biology and fisheries: Volume 1 Fish biology. Oxford: Blackwell Science Ltd; 2002. p.267-83.

Latini OA, Petrere Júnior M. Reduction of a native fish fauna by alien species: an example from Braslian fresh-water tropical lakes. Fisheries Manag Ecol. 2004; 11(2):71-79.

Leprieur F, Beauchard O, Blanchet S, Oberdoff T, Brosse S. Fish invasions in the world's river systems: When natural processes are blurred by human activities. Plos Biol. 2008; 6(12):e322. https://doi.org/10.1371/journal.pbio.0060028

Lima FC. A revision of the cis-andean species of the genus Brycon Müller \& Troschel (Characiformes: Characidae). Zootaxa. 2007; 4222(1):1-189.
Lima LB, Oliveira FJM, Giacomini HC, Lima-Junior DP. Expansion of aquaculture parks and the increasing risk of non-native species invasions in Brazil. Rev Aquacul. 2018; 10(1):111-22.

Lowe-McConnel RH. Ecology of cichlids in South American and African waters, excluding the African great lakes. In: Keenleyside MHA, editor. Cichlids fishes: Behaviour, ecology and evolution. London: Chapman and Hall; 1991. p.60-85.

Lowe S, Browne M, Boudjelas S, De Poorter M. 100 of the world's worst invasive alien species: a selection from the global invasive species database. Auckland: published by the Invasive Species Specialist Group (ISSG) a specialist group of the species survival Commission (SSC) of the World Conservation Union (IUCN); 2000.

Magalhães ALB, Casatti L, Vitule JRS. Alterações no código florestal favorecerão espécies não-nativas de peixes de água doce. Nat Conserv. 2011; 9(1):121-24.

Mollot G, Pantel JH, Romanuk TN. The effects of invasive species on the decline in species richness: a global meta-analysis. Adv Ecol Res. 2017; 56:61-83.

Naylor RL, Williams SL, Strong DR. Aquaculture--a gateway for exotic species. Science. 2001; 294(5547):1655-56.

Njiru M, Mkumbo OC, Van der Knaap M. Some possible factors leading to decline in fish species in Lake Victoria. Aquat Ecosyst Health Manag. 2010; 13(1):3-10.

Ogutu-Ohwayo R. The decline of the native fishes of Lakes Victoria and Kyoga (East Africa) and the impact of introduced species, especially the Nile perch, Lates niloticus, and the Nile Tilapia, Oreochromis niloticus. Environ Biol Fishes. 1990; 27(2):81-96.

Olden JD, Poff NL. Ecological processes driving biotic homogenization: Testing a mechanistic model using fish faunas. Ecology. 2004; 85(7):1867-75.

Orsi ML, Agostinho AA. Introdução de espécies de peixes por escapes acidentais de tanques de cultivo em rios da bacia do rio Paraná, Brasil. Rev Bras Zool. 1999; 16(2):557-60.

Ortega JCG, Júlio Júnior HF, Gomes LC, Agostinho AA. Fish farming as the main driver of fish introductions in Neotropical reservoirs. Hydrobiologia. 2015; 746(1):147-58.

Padial AA, Agostinho AA, Azevedo-Santos VM, Frehse FA, LimaJunior DP, Magalhães ALB, Mormul RP, Pelicice FM, Bezerra LAV, Orsi ML, Petrere-Junior M, Vitule JRS. The "Tilapia Law" encouraging non-native fish threatens Amazonian River basins. Biodivers Conserv. 2017; 26(1):243-46.

Petry AC, Gomes LC, Piana PA, Agostinho AA. The role of the predatory trahira (Pisces: Erythrinidae) in structuring fish assemblages in lakes of a Neotropical floodplain. Hydrobiologia. 2010; 651(1):115-26.

Picker M, Griffiths C. Alien and invasive animals: A South African perspective. Cape Town: Random House Struik (Pty) Ltd; 2011.

Pimentel D, Zuniga R, Morrison D. Update on the environmental and economic costs associated with alien-invasive species in the United States. Ecol Econom. 2005; 52(3): 273-88.

Sabino J, Zuanon J. A stream fish assemblage in central Amazonia: Distribution, activity patterns and feeding behavior. Ichthyol Explor Freshwaters. 1998; 8(3):201-10. 
Santos AFGN, Santos LN, García-Berthou E, Hayashi C. Could native predators help to control invasive fishes? Microcosm experiments with the Neotropical characid, Brycon orbignyanus. Ecol Freshw Fish. 2009; 18(3):491-99.

Santos AFGN, Alcaraz C, Santos LN, Hayashi C. García-Berthou E. Experimental assessment of the effects of a Neotropical nocturnal piscivore on juvenile native and invasive fishes. Neotrop Ichthyol. 2012; 10(1):167-76.

Santos AFGN, García-Berthou E, Hayashi C, Santos LN. When habitat complexity increases predation risk: Experiments with invasive and Neotropical native fishes. Mar Freshwater Res. 2013; 64(8):752-60.

Savino JF, Stein RA. Predation-prey interaction between largemouth bass and bluegills as influenced by simulated, submersed vegetation. T Am Fish Soc. 1982; 111(3):255-66.

Shaw E. Schooling fishes: The school, a truly egalitarian form of organization in which all members of the group are alike in influence, offers substantial benefits to its participants. Am Sci. 1978; 66(2):166-75.

StatSoft, Inc. STATISTICA data analysis software system, version 10. 2011. Available from: http://www.statsoft.com

Strictar-Pereira L, Agostinho AA, Gomes LC. Cage culture with tilapia induces alteration in the diet of natural fish populations: The case of Auchenipterus osteomystax. Braz J Biol. 2010; 70(4):1021-30.

Turner GF, Robinson RL. Reproductive biology, mating systems and parental care. In: Beveridge MCM, McAndrew BJ, editors. Tilapias: Biology and exploitation. Dordrecht: Springer Science+Business Media; 2000. p.33-58.

Van der Waal BCW, Bills R. Oreochromis niloticus (Teleostei: Cichlidae) now in the Limpopo River system. S Afr J Sci. 2000; 96:47-48.
Vicente IST, Fonseca-Alves CE. Impact of introduced Nile tilapia (Oreochromis niloticus) on non-native aquatic ecosystems. Pak J Biol Sci. 2013; 16(3):121-26.

Vitule JRS. Introdução de peixes em ecossistemas continentais brasileiros: Revisão, comentários e sugestões de ações contra o inimigo quase invisível. Neotrop Biol Conserv. 2009; 4(2):111-22.

Vitule JRS, Freire CA, Simberloff D. Introduction of nonnative freshwater fish can certainly be bad. Fish Fish. 2009; 10(1):98-108.

Welcomme RL. Observations on the biology of Introduced species of tilapia in Lake Victoria. Rev Zool Bot Afr. 1967; 76(34):249-79.

Werner EE, Gilliam JF, Hall DJ, Mittelbach GG. An experimental test of the effects of predation risk on habitat use in fish. Ecology. 1983; 6(64):1540-48.

Zaret TM, Paine RT. Species introduction in a tropical lake: A newly introduced piscivore can produce population changes in a wide range of trophic levels. Science. 1973; 182(4111):449-55.

Zhang $\mathrm{Y}$, Zhang Q, Zhang $\mathrm{G}$. $\mathrm{H}_{\infty}$ control of T-S fuzzy fish population logistic model with the invasion of alien species. Neurocomputing. 2016; 173(3):724-33. 